\title{
Liderlik Tarzlarının Çalışanların Bağlılık Seviyesi ve Performansına Etkisi: Başakşehir Belediyesinde Bir Uygulama*
}

Ali DOĞANAY ${ }^{1}$

Erdal ŞEN

\begin{abstract}
Özet
Bu araştırmada, Başakşehir Belediyesinde görevli çalışanların, kurumlarına olan bağlılıkları ve performansları üzerinde, lider personelin sergiledikleri görev ve insan odaklı liderlik tarzlarının etkileri araştırılmıştır. Araştırmada ayrıca örgütsel bağlılık boyutlarının çalışanların performansı üzerindeki etkisi de incelenmiştir. Uygulama kısmında Likert tipi ölçek kullanılarak oluşturulan bir anket Başakşehir Belediyesi'nde 16 farklı birimde ve 15 ayrı pozisyonda görevli kamu çalışanlarından oluşan 163 çalışana uygulanmıştır. Yapılan araştırma sonucunda, görev odaklı liderlik tarzlarının, devam ve normatif bağl1lığa yüksek düzeyde, duygusal bağl1lığa ve çalışan performansına orta düzeyde etki ettiği, insan odaklı liderlik tarzlarının duygusal bağlılık ve çalışan performansına yüksek düzeyde, normatif bağlılığa orta düzeyde etki ederken, devam bağlılı̆̆ üzerinde bir etkisinin olmadığı görülmüştür. Örgütsel bağlılığın çalışanların performansına etkisinde ise duygusal bağlılık dışında, etkili olan bir örgütsel bağl1lık boyutunun olmadığ gözlemlenmiştir.
\end{abstract}

Anahtar Kelimeler: Liderlik Tarzları, Örgütsel Bağlılık, Çalışan Performansı

The Impact of Leadership Styles on Employees' Commitment Level and Performance: An Application in Başakşehir Municipality

\begin{abstract}
In this research the impacts of the task- and people-oriented leadership styles which leader staff exhibit on the organizational commitment and performances of the employees at the Başakşehir Municipality. The study also examines the impact of organizational commitment levels on the performance of employees. A survey study prepared through using Likert-type scale was applied to 163 employees consisting of the public servants engaged in 15 different positions from 16 different units at the Başakşehir Municipality. As a consequence of the research, it was found that task-oriented leadership styles have high and moderate levels of impact on continuance and normative commitment, and emotional commitment and employee performance respectively although peopleoriented leadership styles have high and moderate levels of impact on emotional and employee performance, and normative commitment respectively, but do not have any impacts on continuance commitment. It was observed that there are no effective levels of organisational commitment except for emotional commitment with regard to the impact of organisational commitment on employee performance.
\end{abstract}

Keywords: Leadership Styles, Organizational Commitment, Employee Performance

\section{Giriş}

Günümüz örgütlerinin içinde bulunduğu rekabet koşulları, teknolojik gelişmeler ve buna bağlı olarak organizasyonların sistemlerindeki değişimler gerek mal gerekse hizmet üreten kurum ve kuruluşların bu zorlu koşullarda hayatta kalmalarını güçleştirmektedir. Örgütler, çağın gerisinde kalmamak ve varlıklarını sürdürmek amacıyla bu koşullarda değişime uyum sağlamak zorunda kalmaktadırlar. Bu değişimi gerçekleştirirken gereken teknolojik ve diğer

\footnotetext{
1 Ali Doğanay, İstanbul Gelişim Üniversitesi, Sosyal Bilimler Enstitüsü İşletme Doktora Öğrencisi, alsidoga@hotmail.com

${ }^{2}$ Yrd. Doç. Dr. İstanbul Gelişim Üniversitesi İktisadi, İdari ve Sosyal Bilimler Fakültesi İşletme

Bölümü Öğretim Üyesi, sen@ senizm.com

* Bu makale Yrd. Doç. Dr. Erdal ŞEN danışmanlığında Ali DOĞANAY tarafından hazırlanan

"Liderlik Tarzlarının Çalışanların Bağlılık Seviyesi ve Performansına Etkisi: Başakşehir Belediyesinde Bir Uygulama” başlıklı Yüksek Lisans tezinden uyarlanmıştır.
} 
Yalova Sosyal Bilimler Dergisi

unsurlardan daha büyük öneme sahip olan insan faktörü büyük önem kazanmaktadır. Çünkü insan, kapasitesinin arttırılması ve geliştirilebilmesi sebebiyle bir maliyet unsurundan çok bir yatırım unsuru konumuna gelmiştir.

Liderlik, insan duygularını etkileyen, onu peşinden sürükleyen ve amaç birliği sağlayarak örgütün hedeflerine ulaşmasını sağlayan en önemli etkenlerin başında gelmektedir. Liderlik önemi her geçen gün artan bir kavramdır. Örgütlerde, yeniliği ve değişimi gerçekleştirecek liderlere ihtiyaç duyulmaktadır. Liderlerin sergilediği davranışların görev odaklı ve insan odaklı olması, örgüt içerisinde çalışanların tutumları üzerinde farklı şekilde etki etmektedir (Çekmecelioğlu, 2014: 21). Liderlik insanlık tarihi kadar eski bir kavramdır. İnsanlar, sosyal varlıklar olarak bir arada yaşama eğiliminde olduğundan, gruplardan başlayarak toplumlara kadar farklı düzeylerde etkileşimin olduğu yapıların oluşmasını sağlamıştır. Etkileşimin olduğu birlikteliklerde bazı bireyler diğer bireylerden daha baskın ve ön planda yer almakta ve diğer kişilerin kabulü ile lider olmaktadır. Dolayısıyla liderlik, liderin diğer bireyler ile olan ilişki/etkileşiminin bir sonucu ve kişinin belirli bir grup içerisinde diğerlerinden farklı olarak üstlendiği bir roldür. Başka bir ifadeyle, grup içerisindeki bireyin sergilemiş olduğu bir davranıştır (İbicioğlu, Özmen ve Taş, 2009: 2).

Liderlik, motivasyon, kişiler arası ilişkiler, iletişim süreci ile ilişkilidir. Etkin liderlik, izleyicilere yetkilerin etkili bir şekilde dağıtılma sürecini içerir. Liderlik, liderin davranışları ile sınırlı değildir, aynı zamanda izleyicilerinde davranışlarının bir sonucudur. Liderlik dinamik bir süreçtir. Lider izleyici ilişkisi, iki taraflı bir ilişkidir, etkili liderlik bu ilişside hem izleyicileri, hem de örgüt performansını dikkate alarak yürütülmelidir (Çekmecelioğlu,2014: 22). Bu kapsamda çalışma konumuz olan davranışsal liderlik teorisi, lider davranışlarını inceleyerek bu davranışların çalışanların örgütsel bağlılık ve performansı üzerindeki etkilerini konu almaktadır. $\mathrm{Bu}$ çalışmada davranışsal liderlik çerçevesinde liderlerin göreve ve insana yönelik davranışları geniş bir kapsamda değerlendirilerek, örgütsel bağlılık, iş performansı üzerindeki etkileri yapılan bir araştırma ile incelenmektedir. Türk yönetim ve organizasyon yazını üzerinde yapılan araştırmalar incelendiğinde liderlik ile ilgili teorik ya da ampirik birçok çalışma bulunmasına karşın, liderlik davranışları ve bu davranışların sonuçlarına dair henüz çok da fazla çalışmanın olmadığı görülmektedir. Bu nedenle, bu araştırma ile liderlik yazınına bir katkı sunmak ve yerel yönetimlerde lider davranışlarının çalışanların bağlılık seviyelerine ve performanslarına etkisiyle bu örgütte çalışanların kurumlarına olan bağlılıklarının seviyesinin performanslarına bir etkisinin olup olmadığı ortaya konmaya çalışılacaktır (Çekmecelioğlu, 2004: 22-23).

\section{Liderlikle İlgili Kavramlar}

\subsection{Liderlik ve Lider}

Liderlik, 20. yüzyılda yönetim alanında yoğun olarak yapılan bilimsel çalışmaların en önemli konularından birisi olmuştur. Bu çalışmalarda gerek teorisyenler gerekse uygulayıcılar tarafindan liderlik çözümlenmeye çalışılmış, bu amaçla büyük gayretler sarf edilmiştir. Yoğun gayretler sonucunda liderlikle ilgili 
Yalova Sosyal Bilimler Dergisi

5000 'den fazla araştırma yapılmış ve liderliğe 350'den fazla tanım kazandırılmıştır (Erçetin, 2000: 3). Liderlik, değişik yetki ve sorumluluk düzeylerinde, ilgili sektörün amaçları doğrusunda çalışırken, başkalarının hareketlerini yönetme-idare etme sorumluluğu ve ayrıcalığıdır (Uysal,2007: 17). Liderlik değişim ile başa çıkabilmektir. Liderlik gelecek vizyonu geliştirerek yön çizer; sonra çalışanların bu vizyonu ile iletişim kurmasını ve engelleri aşabilmesini sağlar. (Robbins, 2012: 276). Lider ortak amaçları gerçekleştirmek için grup üyeleri tarafindan gönüllü olarak izlenen kişidir (Drucker, 1993: 139). Bu tanımlardan bir sentez oluşturulacak olursa liderlik kavramı; bir insan grubunu belirlenen hedefler etrafinda örgütlemek ve bu hedefleri hayata geçirmek için kişileri harekete geçirme, etkileme, bilgi ve yeteneklerinin toplamı olarak, lider ise bu değişimi gerçekleştiren bilgi ve yeteneğe sahip kişi olarak tanımlanabilir (Eren, 2010: 435). Liderlikle ilgili bilimsel olarak yapılan ilk çalışmalar 1900 'den sonraki yıllarda yapılmış, 1927 yılından itibaren ise liderlik konusunun önemi daha çok anlaşılmıştır. 1941-1944 tarihleri arasında, liderlikle ilgili çalışmaların sayısında büyük ve önemli artışlar olmuştur. Kurt Lewin ve arkadaşlarının gerçekleştirdiği liderlik çalışmaları bu konunun anlaşılması adına gerçek bir değişikliğe yol açmıştır. Bu dönemden sonra yapılan çalışmalar konunun daha iyi anlaşılmasına yöneliktir (Güney, 2013: 374).

\section{Liderlikte Güç Kaynakları}

Güç, olacak şeylerin yapılmasına karar verme hakkıdır (Tutar ve Erdönmez, 2008: 98). Başka bir ifade ile güç, hedeflere ulaşabilme kabiliyetidir. Psikolojik anlamda bu ulaşma azmin gücü ile fiziksel anlamda ise enerji sarf edilerek gerçekleştirilir (Hodgkinson, 2008: 85). 5 farklı güç kaynağı mevcuttur. $\mathrm{Bu}$ güçler; Yasal güç, Zorlayıcı güç, Ödüllendirme gücü, Karizmatik güç, Uzmanlık gücüdür (Akgündüz, 2001: 18). Yasal güç; astların, liderin ya da yöneticinin kendilerini etkileme hakkına sahip olduğunu kabul etmeleri ile yakından ilişkili olan güç türüdür (Güney, 2013: 385). Zorlayıcı güç, organizasyon çalışanlarının kendilerine verilen görevleri yaparken başarısız olmaları halinde baskı ve korku gibi olumsuz etkiler yapmaya dayanan cezalandırıcı nitelikteki güçtür (Eren, 2010: 391). Ödüllendirme gücü, ödülleri elinde tutma veya üyelere ödül verme gücüdür (Ünal, 2012: 374). Karizma çekiciliği ifade eder ve yöneticinin kişiliğiyle ilgilidir. Karizmatik liderlerin astlara ilham verebilmesi ve onlarında istek ve ümitlerini dile getirebilmesi karizmatik gücün temelini oluşturur (Ataman, 2001: 455). Uzmanlık gücü liderde var olan özel bilgi, liderin uzmanlık yetenek ve deneyimlerinden doğar. Bilginin önemi ne kadar büyük ve daha az insan tarafindan bu bilgilere ulaşılabiliyorsa, liderde bulunan uzmanlık gücü de o kadar fazladır (Ünal, 2012:76).

\section{Liderlik Teorileri}

Süreç içerisinde değişen imkân ve şartlar liderliğin uygulama biçiminde de zamanla değişimler meydana getirmiş ve bu konuya farklı teoriler geliştirilmesine sebep olmuştur. $\mathrm{Bu}$ teoriler, özellikler teorisi, davranışsal liderlik teorisi ve durumsallık teorisi olmak üzere üç grupta toplanmıştır (Sabuncuoğlu ve Tüz, 2003: 
Yalova Sosyal Bilimler Dergisi

220). Özellikler Teorisinde, liderlerin sahip olduğu özellikler belirlenmeye çalışılmıştır (Tahiroğlu, 2005: 78). Bu görüşe göre; liderin temelini doğuştan sahip olduğu nitelik ve yetenekler oluşturmaktadır. Fiziksel ve kişisel özellikler, beceri ve yetenekler ile sosyal etkenler bir lideri diğerlerinden ayıran ve onu etkin kılan özellikler olarak sayılmaktadır (Gürüz ve Özdemir, 2007: 85). Davranışsal Liderlik teorisinde liderin davranışları, liderliğe yaklaşmanın temel noktasını oluşturmaktadır. Liderin izleyicileri karşısında "ne" ve "nasıl” yaptı̆g 1 incelenmektedir. Lider davranışlarının kişilik özelliklerine göre daha kolay gözlemlenebilir ve tanımlanabilir olması bu yaklaşımın savunucularının dayanak noktası olmuştur (Güney, 2013: 393).Durumsal liderlik teorisi ise son yıllarda işletme bilim adamlarının ve uygulayıcılarının üzerinde durdukları bir konudur (Özalp, 1994: 343). Bu liderlik teorisi, liderliği içinde bulunulan koşulları da göz önüne alarak açıklamaya çalışır. Bu teoriye göre, liderin etkinliğini ortaya çıkaran faktör içinde bulunan koşullardır (Tengilimlioğlu, 2008: 116).

\section{Liderlik Tarzları, Görev ve İnsan Odaklı Liderlik}

Liderler otoriter, baskıcı, işbirliği ruhuna sahip, demokrat ve serbest bırakıcı şekilde davranabilirler. Bu liderlik tiplemelerinin ne doğru de de yanlış oldukları söylenemez. Bunun nedeni liderlerin içinde bulundukları durum ve zamana göre uygun tarzı seçme eğilimi göstermeleridir. Grubun yapısı, motivasyon tarzı ve ortamda hangi tarzın geçerli olacağını belirleyecektir (Ekici, 2013: 25) Otokratik liderlik saldırgan ve baskıcı özelliğe sahiptir (Şimşek vd., 1998:141). Bu liderlik tarzında bağlılık çok yüksektir (Ekici, 2013: 35). Bürokratik toplumlarda yetişmiş ve eğitim almış üyelerin beklentilerine uygundur (Eren, 2010: 461). Demokratik liderler ise iş ile ilgili emirlerin çıkarılmasında ve iş bölümü yapılmasında, astlarından aldığı fikir ve düşünceler yönünde liderlik davranışı göstermeye özen gösterirler (Eren, 2010: 461). Grup üyelerinin katılımının bireyin başarı duygusunu yükselteceği ve kişisel gelişmeyi artıracağı düşünülür (Duncan, 1981: 217). Tam Serbestlik Tanıyan Liderlik tarzında lider, kendi otoritesine en az biçimde ihtiyaç duyar. Astlar kendi haline bırakılır (Akgündüz, 2001: 74). Bu liderlik tarzında farklı amaçlar farklı birimler tarafindan takip edildikleri için, bu durum kimi zaman işletmeyi karışıklığa sürükleyebilmektedir (Doğan, 2007: 69). $\mathrm{Bu}$ durum daha çok kargaşa zamanlarında örgütün bozulmasına veya dağılmasına neden olabilir (Sabuncuoğlu ve Tüz, 2003: 219). Transaksiyonel liderlik tarzında davranış gösteren liderler otoritelerini kurmak içen, astlarını ödüllendirme yolunu seçerler (Karaman, 2005: 66). Transaksiyonel liderlik tarzı, geçmişteki olumlu ve faydalı gelenekleri devam ettirme ve bunları sonraki nesillere iletme bakımından yararlı hizmetlerde bulunur (Eren,2010: 465). Bu tarz liderlikte, yönetici kişi ile çalışanların ilişkileri bir değiş-tokuş süreci şeklinde görülmektedir(Saltürk, 2008: 70). Dönüşümcü liderlik tarzı, paylaşılan bir vizyona tercüman olmak, çalışanların düşünsel olarak uyarılması, çalışanların kişisel farklılıklarının izlenmesi konularıyla ilgili liderin becerisi olarak ifade edilebilir (Ünal, 2012: 88). Transformasyonel liderler bir örgütü insanlara seslenmek suretiyle onların saygı ve güvenlerini kazanarak biçimlendirirler. (Harvard Business, 2007: 22-23) Bu tarz liderler, üyelerinin tüm yeteneklerini meydana çıkarırlar ve özgüvenlerini arttırırlar (Eren, 2010: 465). Liderler, astların beklentilerini karşılamanın ötesinde onlara ilham kaynăğ olurlar (Doğan, 2007: 77). Sistem liderliği literatüre yeni 
Yalova Sosyal Bilimler Dergisi

kazandırılmış bir kavramdır. Bir sistem liderinin görevi, bu model çerçevesinde kendisinin bulunmadığı zamanlarda da yaşayan, daima gelişen ve değişen bir anlayışa sahip bir model oluşturmaktır (Ünal, 2012: 85). Karizmatik lider, sahip olunan karizma yaratan niteliklerle, grup üyelerini, kendi istediği yönde davranış göstermeye yöneltebilen, grup üyelerini yüksek performansa sevk eden kişidir (Koçel, 2005: 605). Karizma kavramının bireyler için önemini kaybetmemiş olması nedeniyle bu araştırmalar bugün hala devam etmektedir (Güney, 2013: 411). Hümanist liderlik tarzı ödül sistemini çok sık kullanmaktadır. Lider üyeleri duygusal yönlendirmeyle motive eder. Hümanist liderlik tarzında mecbur kalınmadıkça ceza sistemi uygulanmaz (Sabuncuoğlu ve Tüz, 2003: 218). Vizyoner ve yenilikçi bakış açısına sahip bir lider, diğer yöneticilerden farklı bir biçimde değişik oyları ve gelişmeleri okuyabilme yeteneğine sahip olur. Vizyoner lider, yeni bir bakış açısıyla geleceğe bakabilen kişidir (Ünal, 2012: 85). Otantik liderler, grup üyeleri tarafından, etik kişiler olarak kabul edilirler. Bu sebeple, otantik liderlikten doğan temel sonuç güvendir (Robbins, 2012: 394).

Etkin liderler temsil etme, uzlaşma sağlama, belirsizliği giderme, ikna yeteneği, harekete geçirme, katılım sağlama, üyeleri önemseme, üstlerini etkileme ve üretkenliği arttırmaya önem vermek gibi niteliklere sahip olmalıdır. $\mathrm{Bu}$ niteliklerin göreve ve insana yönelik liderlik tarzları ile ilgili olduğu görülmektedir. Davranışsal liderlik teorisi kapsamında incelenen bu hususlar, literatürde, Ohio State Üniversitesinin liderlik çalışmaları, Michigan Üniversitesi Enstitüsü Araştırmaları, Blake ve Mouton'un Yönetim Tarzı Matriksi ve Likert'in Sistem 4 yaklaşımı ile Liderlik davranışı skalası gibi çalışmalar bulunmaktadır. $\mathrm{Bu}$ çalışmalardan, Ohio State Üniversitesi, Michigan Üniversitesi Enstitüsü Araştırmaları ile Blake ve Mouton'un Yönetim Tarzı Matriksi üzerinde yapılan incelemede liderliğin iki önemli davranışsal boyutu olan göreve ve insana yönelik liderlik tarzları olduğu görülmektedir. Lider, insana yönelik liderlik tarzında, izleyicilerin arzu ve ihtiyaçlarını dikkate alarak tatmin etmeye çalışmakta; organizasyon içinde rahat ve arkadaşça bir hava yaratmakta, ancak işle ilgili girişim, planlama ve organizasyon zayıf düzeyde bulunmaktadır. İnsan (çalışan) odaklı liderler, kişiler arası ilişkilere önem veren kişiler olarak tanımlanır, bu liderler çalışanlarının ihtiyaçlarına kişisel bir ilgi gösterir ve üyeler arasındaki bireysel farklılıkları kabul eder. İnsana yönelik olan liderler, grup performansını yönetmede çalışanın ihtiyaçlarını önemser. Göreve (iş-üretime) yönelik olan liderler ise işin teknik ya da görev yönlerini vurgulamaya eğilimli olup, temel odak noktaları grup amaçlarının gerçekleştirilmesidir. İş odaklı liderler, özellikle iş ile ilgili faaliyetlere odaklanan liderlerdir. Blake ve Mouton ise bu tarz liderliği "otoriter liderlik" olarak tanımlamakta ve liderin iş koşullarını iyi planlamaya, etkin şekilde çalışmaya özen gösterdiği ancak örgüt içindeki insan unsurunun ihmal edildiği bir liderlik stili olarak tanımlamaktadır. Bazı diğer çalışmalarda da, üretim (iş) odaklı liderlik yaklaşımı otokratik liderlik yaklaşımına, çalışan odaklı liderlik yaklaşımı ise, demokratik liderlik yaklaşımına benzetilmektedir (Çekmecelioğlu, 2014: 23). 
Yalova Sosyal Bilimler Dergisi

\section{5. Örgütsel Bağlılık Kavramı}

Örgütsel bağl1lık 1950'lerden sonra yönetim bilgi stokuna girmeye başlamıştır (Griffin ve Hepburn, 2005: 613). Örgütsel bağlılık kavramı son zamanlarda örgütler açısından çok değerli bulunmaktadır. Bunun en önemli nedeni çalışanların olumlu tutumları üzerinde yaptığı değerlendirilen pozitif yönlü etkidir (Özler, 2012: 1). Örgütsel Bağlılık; bir organizasyonun mensubu olarak devam etme yolunda büyük bir istek, örgütün amaç ve değerlerine kesin bir inanç ve kabulü anlatmaktadır. Bağlılık kavramı, çalışanın örgütle özdeşleşme ve örgütte aktif bir şekilde yer almayı devam ettirme arzusunun seviyesi biçiminde de ifade edilir (İbicioğlu, 2000: 19). Örgütsel Bağlılık kavramının bu kadar önemli bir noktaya gelmesinin temel sebebi "insan" unsurudur (Güçlü, 2006: 5-6). Örgütsel bağl1lık duygusunun, örgütsel performansı olumlu yönde etkilediği ve devamsızlık, işten ayrılma ve işe geç gelme gibi istenmeyen sonuçları azalttığı, ayrıca mal ve hizmet kalitesinde artışa neden olduğu öne sürülmektedir (Doğan ve K1lıç, 2007: $38)$.

\subsection{1. Örgütsel Bağlılık Boyutları ve Örgütsel Bağlılığın Sonuçları}

Örgütsel Bağlllıkla ilgili çeşitli ayrımlar bulunmaktadır. Meyer ve Allen (1990) tarafından geliştirilen örgütsel bağl1lık ölçeğinde üç bağlılık türünden söz edilmektedir. Bu bağlılık türleri; duygusal bağl1lık, devam bağl1lı̆g 1 ve normatif bağl1lıktır (Allen ve Meyer, 1990: 1). Duygusal Bağlılık, örgüte bağl1lık literatüründe üzerinde en fazla durulan, yaklaşımdır (Çırpan, 1999: 58). Çalışanların, örgütlerinin amaçlarını, hedeflerini ve değerlerini benimsedikleri ölçüde hissettikleri bağl1lık türüdür(Bayram, 2005: 132). Duygusal bağl1lık çalışanın örgütle bütünleşmesini yansıtır (Balay, 2000:21). Çalışanlar örgütü, kendisi için vazgeçilmez bir varlık, hizmet edilmesi ve yüceltilip yükseltilmesi gereken bir kurum olarak görürler (Eren, 2010: 556-557). Devam bağl1lığı, Çalışanların, çalıştıkları örgüte yapmış oldukları yatırımların sonucunda gelişen bağl1lık türüdür (Bayram, 2005: 133). Devam bağlılığında çalışan; örgütten ayrılmanın maliyetini göze alır ve bunu kabul eder (Balay, 2000: 22). Devam Bağlılı̆̆ı, çalışanların işlerinden sağladıkları maddi ve psiko-sosyal çıkarlara bağ olarak ortaya çıkmaktadır (Eren, 2010: 556). Normatif bağlılık ise diğer bağl1lık boyutlarına nazaran içinde kültür unsurlarını barındıran ve yaşadığı toplumun kültüründen etkilenen bir bağlılık türüdür (Özler, 2012: 6). Bu bağlılık, çalışanın kurumundan ayrılmasından sonra ortaya çıkacak kayıpların hesaplanmasından etkilenmemektedir. (Bayram, 2005: 133) Normatif bağlılığı yüksek olan çalışanlar, örgütte çalışmayı bir sorumluluk ve görev bilincinin bir parçası olarak görürler (Eren, 2010: 557).Örgütsel bağll1ık, örgütlerin amaçlarına ulaşmasında, büyük öneme sahip etkenlerin başında gelmektedir (Bayram, 2005: 133). Örgütsel Bağlılı̆̆ın sağlanması, örgütün verimlilik ve etkinliğini arttıran bir unsur olarak büyük önem taşımaktadır ve örgütte, bağlılık arttırıldığında, işgücü devir hızı azalacak, tecrübeli kişilerle çalışılmaya devam edilecektir (Ada vd., 2008: 489). Nitelikli çalışanların, örgütlerine bağlı olarak çalışması, bütün bilgi ve yeteneklerini örgütü için kullanması, örgütsel bağlılığ çok yakından ilgilendiren bir konudur (Özdevecioğlu, 2003: 113). Örgütsel bağl1lı̆̆ 1 yüksek olan organizasyonlarda işin yenilikçi tasarımları yapılmaktadır (Robbins, 2012: 10-11). 
Örgüt çalışanlarının örgütlerine olan bağlılıkları arttığında işgücü devir hızı azaldığından, çalışanlar istikrar kazanmaktadır (İbicioğlu, 2000: 1). Örgütsel Bağlılık bu yönüyle organizasyonlar açısından büyük önem taşımaktadır (İnce ve Gül, 2005: 13).

\section{6. Çalışan Performansı}

Performans, çalışanın belirli bir zaman aralığı içinde kendisine verilen işi veya görevi yerine getirerek elde ettiği sonuçlardır. Elde edilen sonuçlar olumlu ise, çalışanın görev ve sorumluluklarını başarıyla yerine getirdiği ve yüksek bir performans düzeyine sahip olduğu ortaya çıkmaktadır. Eğer sonuçlar olumsuz ise, çalışanın başarısız olduğu ve performansının düşük olduğu kabul edilir (Özgen, 2001: 209). Performans sadece ortaya çıkan sonuç değildir. Bunun yanında ortaya çıkacak sonuç için tüm eylemlerdeki istek ve o eylemi gerçekleştirmek için gerekli olan gücün ortak çalışması sonucunda oluşan bir ölçümdür (Saldamlı, 2009: 44).

\subsection{Bireysel Performans}

Bireysel performans, örgütün yapılacak işle ulaşmak istediği amaca doğru, bireyin kendisi için belirlenen hedeflere ve standartlara ne ölçüde ulaştığının göstergesidir (Saldaml1, 2009: 43).

\subsection{Bireysel Performansı Oluşturan Unsurlar}

Bireysel performansı oluşturan; "Odaklanma", "Yetkinlik" ve "Adanma" olarak üç unsur bulunmaktadır. Odaklanma da çalışan ne yapacağını bilmeli, Yetkinlikte; çalışan yapacağı işte gerekli yeteneğe sahip olmalı, Adanma'da ise, çalışan bu işi yapmaya istekli olmalıdır. Bu unsurlar birbirinden ayrı ya da iç içe düşünülebilir. Yüksek bireysel performans bu üç unsuru birlikte gerektirdiğinden yönetimin dikkati ve çabası bunların hangisinin ne zaman ve ne kadarının gerektiğini belirlemek üzerine yoğunlaşacaktır (Barutçugil, 2002: 47).

\subsection{Göreve ve İnsana Yönelik Liderlik İle Örgütsel Bağlılık, Çalışan Performansı Arasındaki İlişkiler}

Liderlik tarzı ile örgütsel bağlılık arasındaki ilişki hakkında çeşitli literatürde bir çok araştırma yapılmıştır. Yapılan araştırmalarda liderlik tarzının bağl1lı üzerinde büyük etkileri olduğunu belirlemiştir (Karahan, 2008: 148). Buna göre örgütsel bağlılığın üç özelliği olduğu söylenebilir.Bireyin örgüt amaçlarını kabulü ve bu amaçlara güçlü bir biçimde inanmas1, örgüt için çaba gösterme isteği içinde olması ve örgütte kalmaya devam etme konusunda kesin bir arzu duyması örgütsel bağlılığın göstergesidir. Bu hususların oluşmasında ise liderlik tarzının rolünün büyük olduğu söylenebilir (Balay, 2000: 18).

Takım ve örgüt etkinliğinin sağlanmasında önemli bir role sahip olan liderlik özellikle de lider davranışları proje verimliliğini yakından etkilemektedir. Lider tarafindan sergilenen göreve yönelik davranışlar takım üyelerinin 
tanımlanmış olan görevlerini başarı ile gerçekleştirmelerini ve üretimi arttırmalarını sağlamaktadır. Hedeflerin gerçekleştirilme oranı liderliğin bir anlamda test edilmesidir. Çünkü hedeflere ulaşılması ya da görevlerin başarı ile yerine getirilmesi ancak üyelerle mümkündür. $\mathrm{Bu}$ da gerek proje, gerekse örgütsel hedeflerin gerçekleștirilmesinde liderlerin hem görev hem de insan odaklı davranışlarının ne denli önemli olduğunu ortaya koymaktadır. Liderin göreve (üretime, işe) ve insana yönelik davranışlarının farklı sonuçlar yarattığı tespit edilmektedir. Göreve yönelik davranışlar üretim ve verimliliği arttırırken, insana yönelik davranışları çalışanların iş tatminlerini arttırmaktadır. Bazı araştırmalara göre insan ya da çalışana yönelik liderliğin çalışan tutumları üzerinde pozitif etkileri olduğunu, verimliliği etkilemediğini, diğer yandan, göreve yönelik liderliğin ne tutumlar ne de verimlilik üzerinde açık bir şekilde etkili olmadığını göstermektedir. Çalışana yönelik liderlik tarzında lider, takım çalışmasına önem verir, grup üyelerine koçluk yapar, karar vermede katılımcılığı sağlar. Lider bu davranışları ile üyelerin performansını arttırır. Ancak, liderin hem görev (üretim) hem de insana yönelik davranışları en çok arzu edilen ve takım yönetim stili olarak adlandırılan liderlik tarzı olmasına rağmen, ulaşılması zor bir nokta olarak görülmektedir. Yapılan bazı araştırmalar, teknik ve yönetsel becerilere sahip, çalışan ve takım motivasyonuna önem veren liderler yönetiminde gerçekleştirilen projelerin daha başarılı olduğunu göstermektedir. Türk yönetim-örgütsel davranış yazını incelendiğinde görev ve insana yönelik liderlik tarzlarının genellikle araştırılmadığı görülmektedir. Bu çalışmada göreve ve insana yönelik liderlik tarzlarının örgüte duygusal bağlılık, iş performansı üzerinde pozitif, etkilerinin olacağ 1 düşünülmekte ve bu kapsamda aşağıdaki hipotezler geliştirilmektedir (Çekmecelioğlu, 2014: 26-27).

Tablo 1: Hipotezler

\begin{tabular}{|c|l|}
\hline $\begin{array}{c}\text { Hip. } \\
\text { No. }\end{array}$ & \multicolumn{1}{|c|}{ HİPTEZLER } \\
\hline H1 & $\begin{array}{l}\text { İnsan odaklı liderlik tarzları, çalışanların duygusal bağlılığını pozitif yönde } \\
\text { etkilemektedir. }\end{array}$ \\
\hline H2 & $\begin{array}{l}\text { İnsan odaklı liderlik tarzları, çalışanların duygusal bağlılı̆̆ını görev odaklı } \\
\text { liderlik davranışından daha fazla olumlu etkilemektedir. }\end{array}$ \\
\hline H3 & $\begin{array}{l}\text { Görev odaklı liderlik tarzları, çalışanların devam bağlılığını pozitif yönde } \\
\text { etkilemektedir. }\end{array}$ \\
\hline H4 & $\begin{array}{l}\text { Görev odaklı liderlik tarzları, çalışanların normatif bağlılığını pozitif yönde } \\
\text { etkilemektedir. }\end{array}$ \\
\hline H5 & $\begin{array}{l}\text { İnsan odaklı liderlik tarzları, çalışanların normatif bağlılığını pozitif yönde } \\
\text { etkilemektedir. }\end{array}$ \\
\hline H6 & $\begin{array}{l}\text { Görev odaklı liderlik tarzları, çalışanların performansını pozitif yönde } \\
\text { etkilemektedir. }\end{array}$ \\
\hline H7 & $\begin{array}{l}\text { İnsan odaklı liderlik tarzları çalışanların performansını pozitif yönde } \\
\text { etkilemektedir. }\end{array}$ \\
\hline H8 & Duygusal bağlılık çalışanların performansını pozitif yönde etkilemektedir. \\
\hline H9 & Devam bağlılığı çalışanların performansını pozitif yönde etkilemektedir. \\
\hline H10 & Normatif bağlılık çalışanların performansını pozitif yönde etkilemektedir. \\
\hline
\end{tabular}




\section{Araştırmanın Amacı ve Kapsamı}

$\mathrm{Bu}$ çalışmada amaç, yerel yönetimler kapsamında olan belediyelerde lider konumda olan personelin sergiledikleri liderlik tarzlarının (insan/görev odaklı) çalışanların örgütsel bağlılıkları ve performansına etkisi, sonrasında çalışanların örgütsel bağlılıklarının çalışanların performansına etkisini ölçmektir. $\mathrm{Bu}$ araştırmanın konu kapsamında, liderlik tarzları bağlamında insan ve görev odaklı liderlik tarzları, örgütsel bağl1lık bağlamında duygusal bağl1lık, devam bağl1lı̆̆ ve normatif bağlılık bulunmaktadır. Çalışanların performansı ile kastedilen; çalışanların belirlenen standarda göre iş hedeflerine ulaşmaları, devamsızlık durumları, yaptıkları işten memnuniyet duymaları, moral durumlarıdır.

\subsection{Araştırmanın Kitlesi ve Örneklemi}

$\mathrm{Bu}$ araştırmanın evreni ilçe belediyelerinde görev yapan çeşitli birim ve pozisyonlardaki kamu çalışanlarıdır. Araştırmanın örneklem modeli olasılıklı olmayan örnekleme biçimindedir. Buna göre araştırmaya izin veren bir belediye örnek olarak seçilmiştir. Araştırmanın örneklemi Başakşehir Belediye Başkanlığında çalışan 163 kişiden oluşmaktadır. Araştırma örneklemine katılan çalışanların yaşları 20 ile 53 arasında olup, yaş ortalamaları 36'dır. Eğitim seviyeleri çoğunlukla lise ve üniversite düzeyindedir. Çalışanların toplam görev yapma sürelerine bakıldığında çoğunluğu $(\% 47,9)$ ile $(1-5)$ y1l arasında çalışanlar oluştururken, bulunduğu kadroda $1-5$ yıl çalışanlar yine çoğunluğu oluşturmaktadır. Başakşehir Belediyesi'nin yeni kurulan bir belediye (2008) olmasının bunda etkisi büyüktür. Araştırmaya katılan çalışanlar arasında evli ve bekârlar bulunmakla beraber, evli olanların oranı $(\% 58,9)$ ile bekâr çalışanların oranından fazladır. Araştırmaya göre çalışanlar 16 farklı birimde 15 farklı pozisyonda görev yapmaktadır.

\subsection{Araştırma Modeli ve Hipotezleri}

Araştırmanın modeli, liderlik tarzlarının örgütsel bağlılık boyutları ve çalışan performansı üzerine etkisi ile örgütsel bağlılık boyutlarının çalışan performans1 üzerine olan etkisi üzerine kurulmuştur. Buna göre araştırmanın modeli ve hipotezleri aşağıdaki gibi şekillendirilmiştir.

\section{Şekil 1: Araştırmanın Modeli}

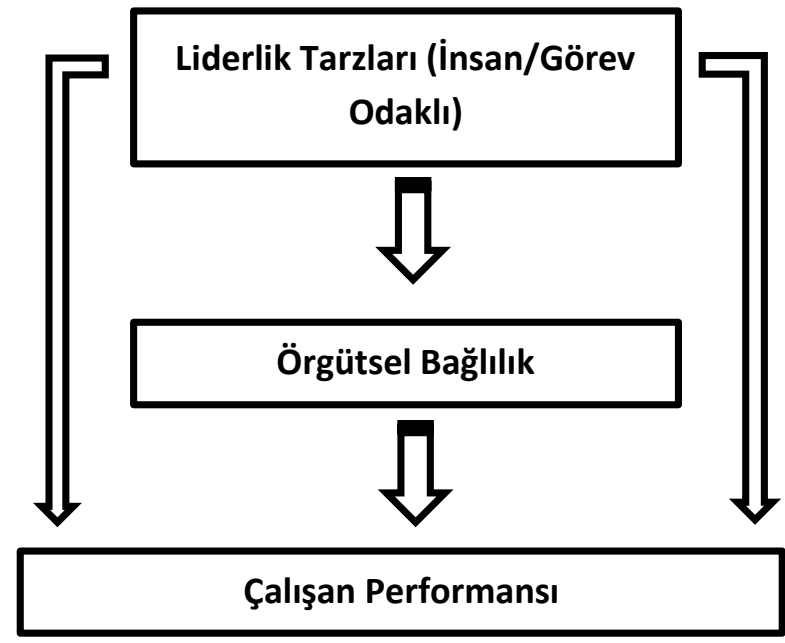




\subsection{Araştırmada Kullanılan Ölçüm Araçları}

Araştırmada veri toplama aracı olarak anket yöntemi kullanılmıştır. Bu maksatla kullanılan liderlik tarzları ölçeği, görev-insan odaklı davranışlarını ölçmek amacıyla tasarlanmıștır. Ölçek Northouse (2013)'un "Leadership: Theory and Practice" kitabından alınmıştır. Ölçek uzmanlar tarafından İngilizce'den Türkçe'ye çevrilmiştir. Daha sonra da alanında uzman bir öğretim üyesi ile birlikte madde madde uygulanacağ 1 örnekleme göre uyarlaması gerçekleştirilmiştir. $\mathrm{Bu}$ kişinin önerilerine göre 2 insan odaklı davranış sorusu, 1 görev odaklı davranış sorusu eklenmiştir. Böylece 11 maddesi insan odakl1, 10 maddesi görev odaklı maddeye sahip 21 soruluk ölçek araştırmada kullanılmıştır. Ölçek Likert tipinde olup; "1: Hiçbir Zaman, 2: Nadiren, 3: Ara-Sıra, 4: Çoğunlukla, 5: Her zaman" biçiminde puanlandırılmıştır.

Örgütsel bağl1lık ölçeği Allen ve Meyer (1997) tarafından geliştirilen ve daha önce Yavuz(2008), Günel(2009), Tekbalkan(2010) ve Kaş (2012)'ın çalışmalarında kullanılan 20 ifadeye sahip bir ölçektir. Bu ölçeğin duygusal bağl1lık, devam bağgl1lğı ve normatif bağl1lık olmak üzeri 3 boyutu bulunmaktadır. Ölçek Likert tipinde olup; "1: Kesinlikle Katılmıyorum, 2: Katılmıyorum, 3: Kararsızım, 4: Katılıyorum, 5: Kesinlikle Katılıyorum” şeklinde puanlandırılmıştır.

Araştırmanın çalışan performansı ölçeği, Kirkman ve Rosen (1999); Fuentes, Saez ve Montes (2004) ve ilaveten Rahman ve Bullock (2004) tarafindan geliştirilen ölçeklerinden hazırlanan ve Erdoğan (2011)'ın çalışmasında kullandığ 1 7 maddeden oluşan ölçektir. Ölçek, Likert tipinde olup; "1: Kesinlikle Katılmıyorum, 2: Katılmıyorum, 3: Kararsızım, 4: Katılıyorum, 5: Kesinlikle Katılıyorum" biçiminde puanlandırılmıştır. Anket sonuçları SPSS 16 paket programıla analiz edilmiştir.

\subsection{Araştırmada Kullanılan İstatistiki Analizler}

Araştırmada önce, demografik bulgular frekans analizleri yardımı ile sunulmuştur. Bundan sonra parametrik analizlerin gerçekleştirilebilmesi için veri tarama işlemi yapılmıştır. Bunun yanında tüm maddeler bazında verilerin $\mathrm{Z}$ değerleri belirlenmiş ve \pm 3 aralığ dışında kalan maddeler analiz kapsamı dışında bırakılmıştır. Tüm bu çalışmalar verilerin daha sağliklı ve parametrik analizlere uygun hale getirilebilmesi için gerçekleştirilmiştir. Daha sonra araştırmada kullanılan görev-insan odaklı liderlik ölçeği ve örgütsel bağlılık ölçeği ile çalışan performansı ölçeği üzerinde yapısal geçerliliği sınamak amacıyla faktör analizleri gerçekleştirilmiştir. Araştırma modeli kapsamında kurulan hipotezlerin testi için çoklu regresyon analizi gerçekleştirilmiştir.

\subsection{Araştırmanın Sınırıılıkları}

$\mathrm{Bu}$ araştırma diğer araştırmalara benzer bazı sınırlılıklar taşımaktadır. Kamu kurumlarında çalışanların araştırmalara tereddütle yaklaşması, sınırlı sayıda bir örneklem hacminin olması, araştırmaya örnek olarak seçilen kurumun tesadüfi olmayan biçimde seçimi ve tüm çalışanlara ulaşılamama durumu bu araştırmanın 
Yalova Sosyal Bilimler Dergisi

sinırlılıklarıdır. Ayrıca bireyin kendi performansı ile ilgili ne derecede objektif olacağı sorusu bu araştırmanın kısıtlarından birini oluşturmaktadır.

\section{Araştırmanın Bulguları}

\subsection{Demografik Değişkenlerin Bulguları}

Araştırma örneklemine katılan çalışanların yaşları 20 ile 53 arasında olup, yaş ortalamaları 36'dır. Eğitim seviyeleri çoğunlukla lise ve üniversite düzeyindedir. Çalışanların toplam görev yapma sürelerine bakıldığında çoğunluğu $(\% 47,9)$ ile (1-5) yıl arasında çalışanlar oluştururken, bulunduğu kadroda 1-5 y1l çalışanlar yine çoğunluğu oluşturmaktadır. Başakşehir Belediyesi'nin yeni kurulan bir belediye (2008) olmasının bunda etkisi büyüktür. Araştırmaya katılan çalışanlar arasında evli ve bekârlar bulunmakla beraber, evli olanların oranı $(\% 58,9)$ ile bekâr çalışanların oranından fazladır. Araştırmaya göre çalışanlar 16 farklı birimde 15 farklı pozisyonda görev yapmaktadır.

\subsection{Liderlik Tarzları, Örgütsel Bağlılık ve Çalışan Performansı Ölçeği Faktör Analizi Bulguları}

Görev-insan odaklı liderlik tarzları ölçeğinde toplamda 21 madde bulunmasına karşılık ilgili geçerlilik ve güvenilirlik analizleri sonrasında geriye 16 madde kalmıştır. Örgütsel Bağlllık Ölçeğinde toplamda 20 madde bulunmasına karşılık, ilgili geçerlilik ve güvenilirlik analizleri sonrasında geriye 14 madde kalmıştır. Çalışan performansı ölçeğinde toplamda 7 madde bulunmasına karşılık ilgili geçerlilik ve güvenilirlik analizleri sonrasında geriye 6 madde kalmıştır. Analiz dışı bırakılan maddeler ilk olarak faktör analizi bulgularına dayanarak belirlenmiştir. Faktör yükü 0,50'nin altında kalan maddelerin ölçekten çıkarılması uygun görülmüştür. Zira Hair ve diğerleri 0,50 faktör yükünü faktörlerin ayrıştırılması açısından en sağlıklı değer olarak görmüştür (Hair vd., 1998: 385). Yapılan faktör analizi sonucunda Liderlik Tarzları Ölçeği Kaiser-Meyer-Olkin (KMO) değeri 0.913, Örgütsel Bağl1lık Ölçeği KMO değeri 0,895, Çalışan Performansı Ölçeği KMO değeri 0,797 gibi oldukça yüksek kabul edilebilecek bir oran olarak bulunmuştur. Bu değer faktör analizi için yeterli olarak görülmektedir. Elde edilen değerler, veri setinin faktör analizi için uygun olduğunu göstermektedir (Kalayc1, 2005: 322).

Tablo 2: Görev-İnsan Odaklı Lider Davranışlarına İlişkin Açıklayıcı Faktör Analizi Tablosu

\begin{tabular}{|c|c|c|c|}
\hline $\begin{array}{l}\text { İnsan Odaklı Liderlik } \\
\text { Tarzları İfadeleri }\end{array}$ & $\begin{array}{c}\text { Faktör } \\
\text { Ortalaması }\end{array}$ & Faktör Yükleri & $\begin{array}{c}\text { Cronbach } \\
\text { Alpha }\end{array}$ \\
\hline $\begin{array}{lr}\text { İ2) Amirim } & \text { çalışma } \\
\text { ortamında } & \text { astlarının } \\
\text { kendilerini } & \text { rahat } \\
\text { hissetmelerini sağlar. } & \end{array}$ & 4.1723 & 0.839 & 0.919 \\
\hline
\end{tabular}


(İ6) Amirim astlar1 ile iyi iletişim halindedir.

(İ) Amirim astlar1 tarafından yapılan görüş ve önerilere açıktır.

(İ4) Amirim astlarına karş1 adil davranır.

(İ5) Amirim astlarına karş1 davranışlarında tutarlıdır.

(I7) Amirim astlarının çalışma ortamında huzurlu olmasına özen gösterir.

(İ8) Amirim kararlarını alırken esneklik gösterir.

(İ1) Amirim personelinin duygularını ve sorunlarını önemser.

(İ1) Amirim astlarına karş1 cana yakın davranır.

(i9) Amirim kendi duygularını düşüncelerini bizlerle

(I10) Amirim astlarının birbirleri ile iyi ilişkiler içerisinde olmalarını ister.

Görev Odaklı Liderlik (G8) Amirim astlarından sürekli daha iyi çalışmalarını ister.

(G6) Amirim her zaman astlarına karşı kendi rolünü ve otoritesini vurgular.

(G7) Amirim her görevde beklentilerinin ve kriterlerinin ne olduğunu (G1) Amirim astlarına. görevlerine yönelik olarak yapmas1 gerekenleri sürekli olarak söyler.

(G10) Amirim. verdiği görevlerin zamanından önce tamamlanmasını ister.

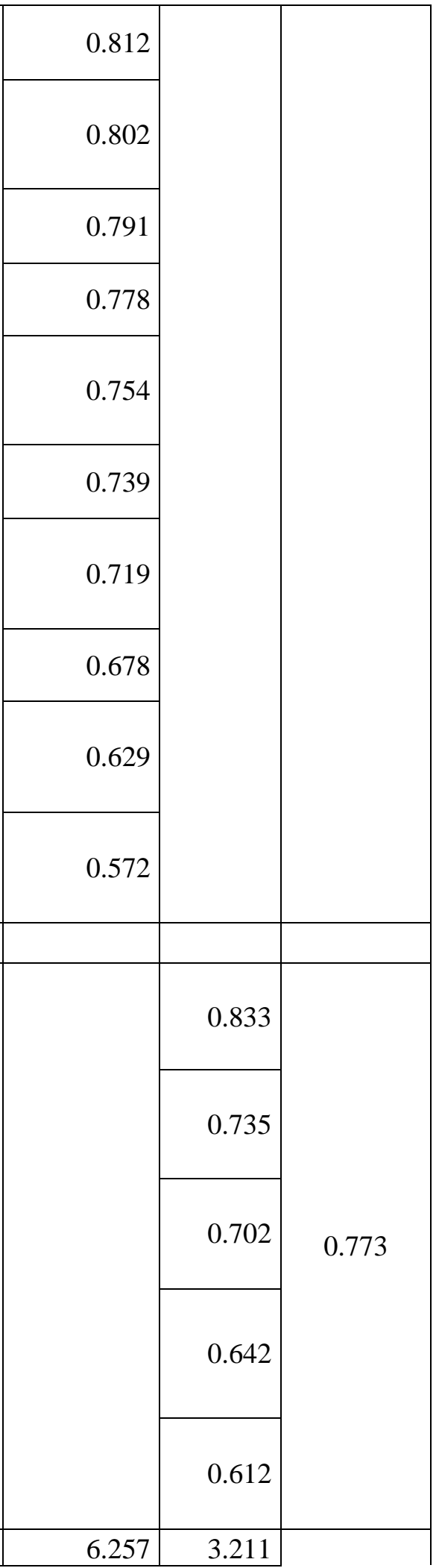




\begin{tabular}{|r|r|r|}
\hline Açlklanan Varyans & $\% 39.108$ & $\% 20.067$ \\
\hline Skewness & -1.348 & -.925 \\
\hline Kurtosis & 1.857 & 0.875 \\
\hline $\begin{array}{l}\text { Toplam Açıklanan Varyans: \%59.174 } \\
\text { KMO Değeri:0.913 }\end{array}$ \\
\hline
\end{tabular}

*İ: İnsan Odaklı Liderlik Tarzları İfadeleri. G: Görev Odaklı Liderlik Tarzları Ífadeleri

Tablo 3: Örgütsel Bağlılığa İlişskin Açıklayıcı Faktör Analizi Tablosu

\begin{tabular}{|c|c|c|c|}
\hline $\begin{array}{l}\text { Duygusal Bağlılık } \\
\text { Maddeleri }\end{array}$ & $\begin{array}{l}\text { Faktör } \\
\text { Ort. }\end{array}$ & & $\begin{array}{c}\text { Cronbach } \\
\text { Alpha }\end{array}$ \\
\hline $\begin{array}{l}\text { (D6) Çalıştığım belediyeye } \\
\text { karşı çok güçlü bir aidiyet } \\
\text { duygusu hissediyorum. }\end{array}$ & \multirow{7}{*}{3.9895} & 0.885 & \multirow{7}{*}{0.938} \\
\hline $\begin{array}{l}\text { (D3) Bu belediyede } \\
\text { kendimi "ailenin bir } \\
\text { parçası" gibi hissediyorum. }\end{array}$ & & 0.875 & \\
\hline \begin{tabular}{llr} 
(D4) Bu & \multicolumn{2}{c}{ belediyeye } \\
duygusal & bir & bağ \\
hissediyorum. & &
\end{tabular} & & 0.848 & \\
\hline $\begin{array}{l}\text { (D5) Bu belediye benim } \\
\text { için çok fazla kişisel anlam } \\
\text { taşıyor. }\end{array}$ & & 0.842 & \\
\hline $\begin{array}{lr}\text { (D7) } & \text { Çalıştığım } \\
\text { belediyeden } & \text { dişarıdaki } \\
\text { insanlara } & \text { gururla } \\
\text { bahsediyorum. } & \\
\end{array}$ & & 0.799 & \\
\hline $\begin{array}{l}\text { (D1) Meslek hayatımın } \\
\text { geriye kalanını bu } \\
\text { belediyede geçirmekten } \\
\text { mutluluk duyarım. }\end{array}$ & & 0.778 & \\
\hline $\begin{array}{l}\text { (D2) Çalıştığım } \\
\text { belediyenin problemlerini } \\
\text { kendi problemim gibi } \\
\text { hissediyorum. }\end{array}$ & & 0.737 & \\
\hline Devam Bağlılığı & & & \\
\hline
\end{tabular}




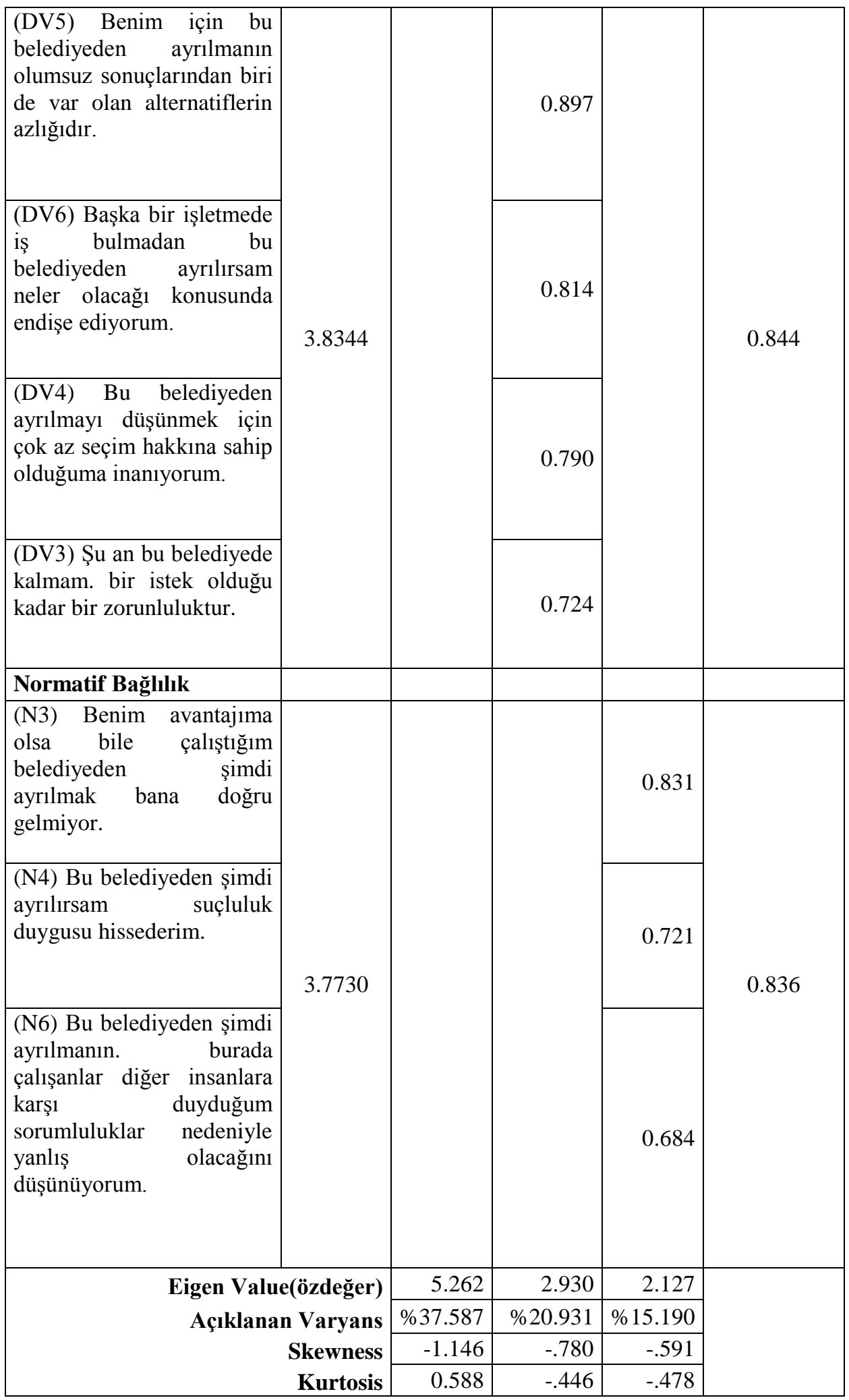


*D: Duygusal Bağl1lık Ölçeği. DV: Devam Bağl1lığı Ölçeği. N: Normatif Bağl1lık Ölçeği.

Tablo 4: Çalışan Performansına İlişkin Açıklayıcı Faktör Analizi Tablosu

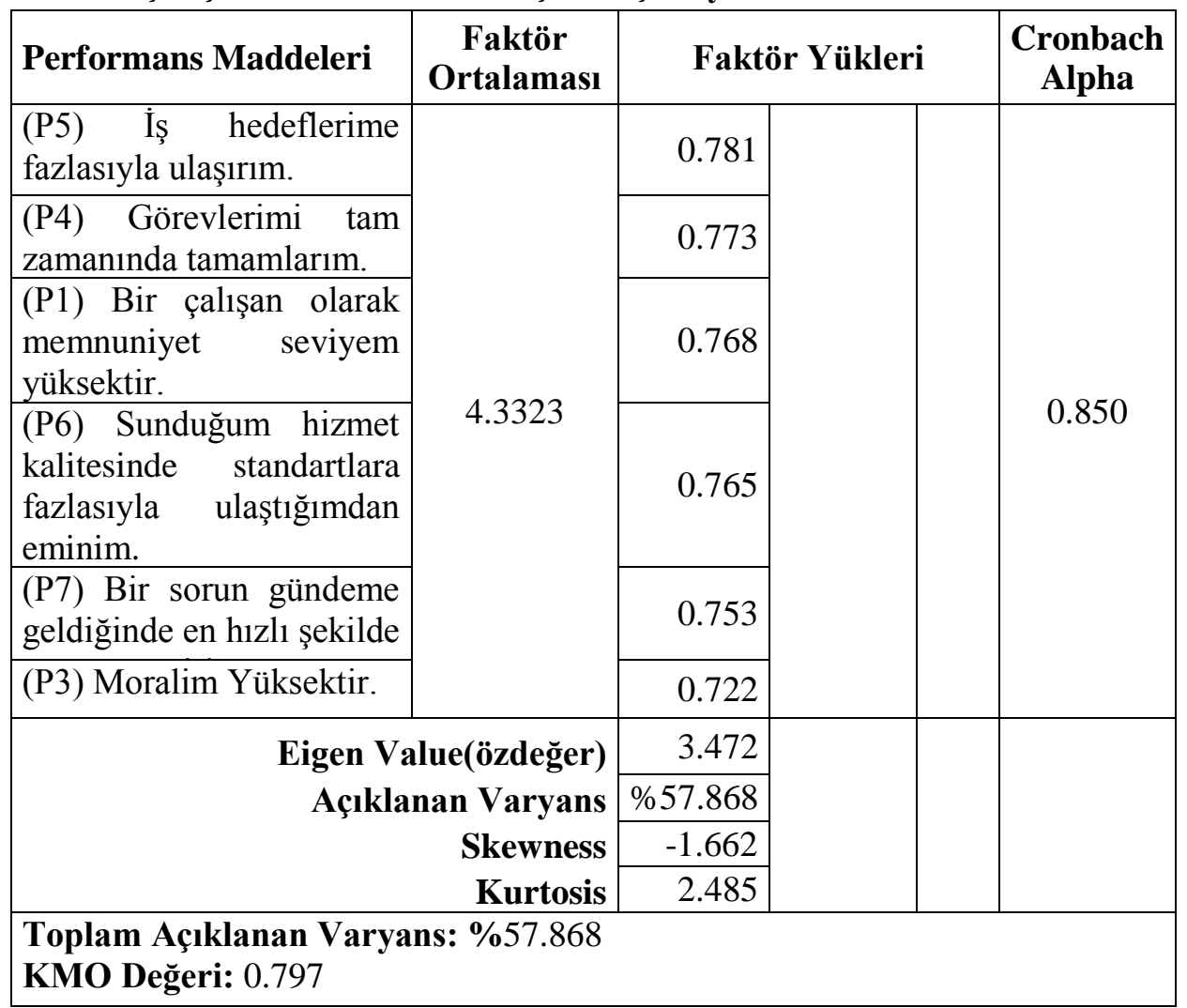

*P: Performans Ölçeği

Liderlik tarzları ölçeği faktör analizi bulgularına göre iki faktör için toplam açıklanan varyans oranı 59.174'tür. Görev odaklı liderlik tarzları faktörüne katılımcıların verdikleri ortalama değer 4.0859. insan odaklı liderlik faktörüne verdikleri değer ise 4.1723 'tür. Örgütsel Bağll1ı ölçeği faktör analizi bulgularına göre iki faktör için toplam açıklanan varyans oran1 \%73.708'dir. Duygusal bağl1lık faktörüne katılımcıların verdikleri ortalama değer 3.9895. Devam Bağlılı̆̆ faktörüne katılımcıların verdiği ortalama değer 3.8344. normatif bağl1lık faktörüne katılımcıların verdiği ortalama değer ise 3.7730 'dır. Çalışan performansı ölçeği. faktör analizi bulgularına göre çalışan performansı faktörü için toplam açıklanan varyans oran $1 \% 57.868$ 'dir. Çalışan performansı faktörüne katılımcıların verdikleri ortalama değer 4.3323 'tür. Faktörlerin öz değerleri de gerekli olan 1 değerinden önemli derecede yüksek görülmektedir. Bunların yanında verilerin faktörler bazında normal dağılıma uyup uymadığı da çarpıklık ve basıklık değerlerine bakılarak ifade edilebilir. Bu değerlere bakıldığında her iki faktör için çarpıklık ve basıklık değerlerinin \pm 3 aralığında olduğu görülmektedir. Bu değerler arasındaki 
veri setlerinin normal dağılıma uygun olduğu varsayılmalıdır. (Kalaycı. 2005: 322). Bu yüzden ortalama değerler üzerinden de yorumlar yapılabilir. Örneklem sayısı da bu dağılıma uygunluk açısından yeterli düzeydedir. Görev odaklı liderlik tarzları faktörünün güvenilirlik katsayısı 0.773 . insan odaklı liderlik tarzları güvenilirlik katsayıs1 0.919 düzeyindedir. Duygusal bağl1lık faktörünün güvenilirlik katsayısı 0.938. devam bağlılığı faktörünün güvenirlik katsayısı. 0.844. Normatif Bağlılık faktörünün güvenirlik katsayısı ise 0.836 düzeyindedir. Çalışan performansı güvenilirlik katsayısı 0.850 'dir. Bu değerler (Kalayc1. 2005) oldukça güvenilir düzeydedir. Böylece maddelerin ilgili faktörlere doğru bir şekilde dağıldığı ve ölçeklerin yapısal geçerliliği varsayımının doğrulandığı yorumu yapılabilir. $\mathrm{Bu}$ ölçeğin bu madde ve örneklem bağlamında geçerliliği ve güvenilirliği yeterli düzeyde ve parametrik testlere uygun halde olduğu belirlenmiştir.

\section{Hipotez Testlerine Yönelik Regresyon Analizi Bulguları}

Araştırmanın modeli kısmında belirtilen hipotezler bağımsız değişkenin bağımlı değişkene istatistiki olarak anlamlı etkisini sorgulayan hipotez türleridir. $\mathrm{Bu}$ hipotezleri test etmek amaciyla regresyon analizi tercih edilmiştir.

Tablo 5: Regresyon Analizi Bulguları Model 1

\begin{tabular}{|l|c|c|}
\hline \multicolumn{3}{|c|}{ Model 1 } \\
\hline $\begin{array}{l}\text { Faktörler (Bağımsız } \\
\text { Değişkenler) }\end{array}$ & B(beta) & $\begin{array}{l}\text { Sig. } \\
\text { (Anlamlılık }\end{array}$ \\
\hline Görev Odaklı Lider Tarzları & 0.273 & 0.000 \\
\hline İnsan Odaklı Lider Tarzları & 0.576 & 0.000 \\
\hline \multicolumn{3}{|c|}{ Bağımlı Değişken: Duygusal Bağlılık } \\
\hline \multicolumn{2}{|c|}{ R2: 0.548} \\
\hline \multicolumn{2}{|c|}{ F: 96.848} \\
\hline \multicolumn{3}{|c|}{ Modelin Anlamlı̆ığı: 0.000.} \\
\hline
\end{tabular}

Model 1'e bakıldığında görev odaklı liderlik tarzlarının duygusal bağlılığa pozitif yönde ve anlamlı $(\mathrm{p}<0.001)$ bir etkisinin olduğu görülmektedir. İstatistiki olarak yorumlamak gerekirse görev odaklı liderlik tarzlarındaki 1 birimlik artış. duygusal bağl1lığa (0.273) birimlik artış sağlamaktadır $(\mathrm{p}<0.001)$.

İnsan odaklı liderlik tarzlarının da duygusal bağlılık üzerinde pozitif yönde ve anlamlı bir etki yaptığı görülmüştür. İstatistiki olarak yorumlamak gerekirse de. insan odaklı liderlik tarzlarındaki 1 birimlik artış duygusal bağlılığa (0.576) birimlik artış sağladığı görülmektedir(p<0.001). Bu bağlamda "H1: İnsan odaklı liderlik davranışı çalışanların duygusal bağl1lığını istatistiki olarak anlamlı ve pozitif yönde etkilemektedir" ve insan odaklı liderlik tarzlarının etkisinin. görev odaklı liderlik tarzlarının etkisinden yüksek olması sebebiyle "H2: İnsan odaklı 
Yalova Sosyal Bilimler Dergisi

liderlik tarzları çalışanların duygusal bağlılı̆̆ını görev odaklı liderlik tarzlarından daha fazla olumlu etkilemektedir" hipotezleri kabul edilmiştir.

Araştırma modeli kapsamında ikinci olarak devam bağl1lı̆̆ bağımlı değişken olarak kurgulanmıştır.

Tablo 6: Regresyon Analiz Bulguları Model 2

\begin{tabular}{|l|r|r|}
\hline \multicolumn{3}{|c|}{ Model 2 } \\
\hline $\begin{array}{l}\text { Faktörler (Bağımsız } \\
\text { Değişkenler) }\end{array}$ & B(beta) & $\begin{array}{l}\text { Sig. } \\
\text { (Anlamlılık }\end{array}$ \\
\hline Görev Odaklı Lider Tarzları & 0.358 & 0.000 \\
\hline İnsan Odakı Lider Tarzları & -0.029 & 0.728 \\
\hline \multicolumn{3}{|c|}{ Bağımlı Değişken: Devam Bağlı1ı̆̆ } \\
\hline \multicolumn{3}{|c|}{ R2: Fod 10.899} \\
\hline \multicolumn{3}{|c|}{ Modin Anlamılığı: 0.000.} \\
\hline
\end{tabular}

Model 2'ye bakıldığında görev odaklı liderlik tarzlarının devam bağlılığı üzerinde pozitif yönde ve anlamlı $(\mathrm{p}<0.001)$ bir etkisinin olduğu gözükmektedir. İstatistiki olarak yorumlamak gerekirse görev odaklı liderlik tarzlarındaki 1 birimlik artış. devam bağlılığına (0.358) birimlik artış sağlamaktadır $(\mathrm{p}<0.001) . \mathrm{Bu}$ sonuçla "H3: Görev odaklı liderlik tarzları çalışanların devam bağlılığını istatistiki olarak anlamlı ve pozitif yönde etkilemektedir" hipotezi kabul edilmektedir.

İnsan odaklı liderlik tarzlarının ise devam bağlılığı üzerinde negatif yönde etkili olduğu. bu etkinin istatistiki olarak anlamlı bulunmadığı görülmektedir( $\mathrm{p}=0.728)$.

Araştırma modeli kapsamında üçüncü olarak normatif bağl1lık bağımlı değişken olarak kurgulanmıştır.

Tablo 7: Regresyon Analiz Bulguları Model 3

\begin{tabular}{|c|c|c|}
\hline \multicolumn{3}{|c|}{ Model 3} \\
\hline $\begin{array}{l}\text { Faktörler (Bağımsız } \\
\text { Değişkenler) }\end{array}$ & B(beta) & $\begin{array}{l}\text { Sig. } \\
\text { (Anlamlılı }\end{array}$ \\
\hline Görev Odaklı Lider Tarzları & 0.370 & 0.000 \\
\hline 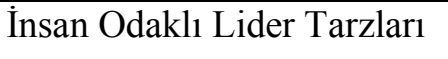 & 0.295 & 0.000 \\
\hline \multicolumn{3}{|c|}{ Bağımlı Değişken: Normatif Bağl1lık } \\
\hline \multicolumn{3}{|r|}{ R2: 0.322} \\
\hline \multicolumn{3}{|r|}{ F: 38.028} \\
\hline & An & lığı: 0.000 . \\
\hline
\end{tabular}


Model 3'e bakıldığında görev odaklı liderlik tarzlarının normatif bağl1lık üzerinde pozitif yönde ve anlamlı $(\mathrm{p}<0.001)$ bir etkisinin olduğu gözükmektedir. İstatistiki olarak yorumlamak gerekirse görev odaklı liderlik tarzlarındaki 1 birimlik artış. normatif bağl1lığa (0.370) birimlik artış sağlamaktadır $(\mathrm{p}<0.001) . \mathrm{Bu}$ sonuçla "H4: Görev odaklı liderlik tarzları çalışanların normatif bağlılığını istatistiki olarak anlamlı ve pozitif yönde etkilemektedir" hipotezi kabul edilmektedir. İnsan odaklı liderlik tarzlarının ise normatif bağl1lık üzerinde pozitif yönde ve anlamlı bir etkisinin olduğu görülmektedir. İstatistiki olarak insan odaklı liderlik tarzlarındaki 1 birimlik artış. normatif bağl1lığa (0.295) birimlik artış sağlamaktadır $(\mathrm{p}<0.001)$. Bu bağlamda "H5: İnsan odaklı liderlik tarzları çalışanların normatif bağlılı̆̆ını istatistiki olarak anlamlı ve pozitif yönde etkilemektedir" hipotezi kabul edilmektedir. Görev ve insan odaklı liderlik tarzlarının normatif bağlılığa etkisinde. görev odaklı lider tarzlarının. insan odaklı liderlik tarzlarından fazla etkili olduğu görülmektedir.

Araştırma modeli kapsamında dördüncü olarak çalışan performansı bağımlı değişken olarak kurgulanmıştır.

Tablo 8: Regresyon Analiz Bulguları Model 4

\begin{tabular}{|l|r|r|}
\hline \multicolumn{3}{|c|}{ Model 4 } \\
\hline $\begin{array}{l}\text { Faktörler } \\
\text { (Bağımsız Değişkenler) }\end{array}$ & B(beta) & $\begin{array}{l}\text { Sig. } \\
\text { (Anlamıı }\end{array}$ \\
\hline Görev Odaklı Lider Tarzları & 0.278 & 0.000 \\
\hline İnsan Odaklı Lider Tarzları & 0.499 & 0.000 \\
\hline \multicolumn{3}{|c|}{ Bağımlı Değişken: Çalışan performansı } \\
\hline \multicolumn{3}{|c|}{ R2: 0.452} \\
\hline \multicolumn{3}{|c|}{ Fodelin Anlamılı̆ı̆ı: 0.000.} \\
\hline
\end{tabular}

Model 4'te görev odaklı liderlik tarzlarının çalışan performansı üzerinde pozitif yönde ve anlamlı bir etkisinin olduğu gözükmektedir. İstatistiki olarak görev odaklı liderlik tarzlarındaki 1 birimlik artış. çalışan performansına (0.278) birimlik artış sağlamaktadır $(p<0.001)$. Bu sonuçla "H6: Görev odaklı liderlik tarzları çalışanların performansını istatistiki olarak anlamlı ve pozitif yönde etkilemektedir" kabul edilmektedir.

İnsan odaklı liderlik tarzlarının çalışan performansı üzerinde pozitif yönde ve anlamlı bir etkisinin olduğu görülmektedir. İstatistiki olarak. insan odaklı liderlik tarzlarındaki 1 birimlik artış. normatif bağl1lığa (0.499) birimlik artış sağlamaktadır $(\mathrm{p}<0.001)$. Bu bağlamda "H7: İnsan odaklı liderlik davranış1 çalışanların performansını istatistiki olarak anlamlı ve pozitif yönde etkilemektedir" hipotezi kabul edilmektedir. Görev ve insan odaklı liderlik tarzlarının normatif bağlılığa etkisinde. göreve odaklı liderlik tarzlarının. insan odaklı liderlik tarzlarından daha fazla etkili olduğu görülmektedir. 
Yalova Sosyal Bilimler Dergisi

Araştırma modeli kapsamında bağımlı değişken olarak seçilen çalışan performansı üzerine Duygusal. Devam ve Normatif Bağl1lık etkisinin bulguları Model 5'te gösterilmiştir.

Tablo 9: Regresyon Analiz Bulguları Model 5

\begin{tabular}{|l|c|c|}
\hline \multicolumn{3}{|c|}{ Model 5 } \\
\hline $\begin{array}{l}\text { Faktörler } \\
\text { (Bağımsız Değişkenler) }\end{array}$ & B(beta) & $\begin{array}{l}\text { Sig. } \\
\text { (Anlamlılık }\end{array}$ \\
\hline Duygusal Bağl1lık & 0.679 & 0.000 \\
\hline Devam Bağl11ığı & -0.052 & 0.413 \\
\hline Normatif Bağlılık & 0.030 & 0.708 \\
\hline \multicolumn{3}{|c|}{ Bağımlı Değişken: Çalışan Performans1 } \\
\hline \multicolumn{3}{|c|}{ R73 } \\
\hline \multicolumn{3}{|c|}{ Modelin Anlamlılığı: 0.000.} \\
\hline
\end{tabular}

Model 5 incelendiğinde birinci boyutta bulunan duygusal bağl1lı̆̆ın. çalışan performansı üzerinde pozitif yönde ve anlamlı bir etkisinin olduğu görülmektedir. İstatistiki olarak duygusal bağl111kta 1 birimlik artış. çalışan performansına (0.679) birimlik artış sağlamaktadır $(\mathrm{p}<0.001)$. Bu sonuçla " $\mathrm{Bu}$ sonuçla "H8: Duygusal bağlılık çalışanların performansını istatistiki olarak anlamlı ve pozitif yönde etkilemektedir" hipotezi kabul edilmektedir.

Model 5'de devam bağlılığının. çalışan performansı üzerindeki etkisi negatif yönde olup anlamlı bir etki taşımamaktadır. $(\mathrm{p}=0.415) \quad B u$ veriler 1 şı̆̆ında "H9: Devam bağlılı̆̆ çalışanların performansını istatistiki olarak anlamlı ve pozitif yönde etkilemektedir" hipotezi kabul edilmemiştir.

Model 5'de Normatif Bağlılığının. çalışan performansı üzerindeki etkisi pozitif yönde olmasına rağmen anlamlı bir etki taşımamaktadır. $(p=0.708) \mathrm{Bu}$ bağlamda "H10: Normatif bağlılık çalışanların performansını istatistiki olarak anlamlı ve pozitif yönde etkilemektedir" hipotezi kabul edilmemiştir. Hipotez testlerine yönelik analiz sonuçları Tablo-10'de gösterilmiştir. Analiz sonuçlarına göre. araştırmanın modeli ve hipotezler kısmında oluşturulan 10 hipotezden 8'i kabul edilmiş. 2 hipotez reddedilmiştir.

Tablo 10: Hipotez Testlerine Yönelik Analiz Sonuçlarının Tablo Olarak Gösterilmesi

\begin{tabular}{|c|l|c|c|}
\hline HïP.NO. & \multicolumn{1}{|c|}{ HİPOTEZ } & KABUL/RED \\
\hline H1 & $\begin{array}{l}\text { İnsan odaklı liderlik tarzları çalışanların } \\
\text { duygusal bağlılığını pozitif yönde } \\
\text { etkilemektedir. }\end{array}$ & $\begin{array}{l}\text { KABUL } \\
\text { EDİLDİ }\end{array}$ \\
\hline H2 & $\begin{array}{l}\text { İnsan odaklı liderlik tarzları çalışanların } \\
\text { duygusal bağl1lığını görev odaklı liderlik } \\
\text { davranışından daha fazla olumlu etkilemektedir. }\end{array}$ & $\begin{array}{l}\text { KABUL } \\
\text { EDİLDİ }\end{array}$ \\
\hline
\end{tabular}




\begin{tabular}{|c|c|c|}
\hline $\mathrm{H} 3$ & $\begin{array}{l}\text { Görev odaklı liderlik tarzları, çalışanların devam } \\
\text { bağlıllı̆ını pozitif yönde etkilemektedir. }\end{array}$ & $\begin{array}{l}\text { KABUL } \\
\text { EDILDI }\end{array}$ \\
\hline $\mathrm{H} 4$ & $\begin{array}{l}\text { Görev odaklı liderlik tarzları. çalışanların } \\
\text { normatif bağl1lığını pozitif yönde etkilemektedir. }\end{array}$ & $\begin{array}{l}\text { KABUL } \\
\text { EDİLDI }\end{array}$ \\
\hline H5 & $\begin{array}{l}\text { İnsan odakl1 liderlik tarzları, çalışanların } \\
\text { normatif bağl1lığını pozitif yönde etkilemektedir. }\end{array}$ & $\begin{array}{l}\text { KABUL } \\
\text { EDILDI }\end{array}$ \\
\hline H6 & $\begin{array}{l}\text { Görev odaklı liderlik tarzları. çalışanların } \\
\text { performansını pozitif yönde etkilemektedir. }\end{array}$ & $\begin{array}{l}\text { KABUL } \\
\text { EDİLDI }\end{array}$ \\
\hline H7 & $\begin{array}{l}\text { İnsan odaklı liderlik tarzları çalışanların } \\
\text { performansını pozitif yönde etkilemektedir. }\end{array}$ & $\begin{array}{l}\text { KABUL } \\
\text { EDILDI }\end{array}$ \\
\hline H8 & $\begin{array}{l}\text { Duygusal bağl1lık çalışanların performansını } \\
\text { pozitif yönde etkilemektedir. }\end{array}$ & $\begin{array}{l}\text { KABUL } \\
\text { EDİLDİ }\end{array}$ \\
\hline H9 & $\begin{array}{l}\text { Devam bağl11ığ çalışanların performansını } \\
\text { pozitif yönde etkilemektedir. }\end{array}$ & $\begin{array}{l}\text { RED } \\
\text { EDILDI }\end{array}$ \\
\hline H10 & $\begin{array}{l}\text { Normatif bağl1lik çalışanların performansını } \\
\text { pozitif yönde etkilemektedir. }\end{array}$ & $\begin{array}{l}\text { RED } \\
\text { EDILDI }\end{array}$ \\
\hline
\end{tabular}

\section{Sonuc}

Liderlik literatürüne bakıldığı zaman davranıșsal liderlik teorisinin, liderlerin çalışanlar ve örgüt üzerindeki etkisini açıklamak açısından önemli bir yerinin olduğu görülmektedir. Ancak göreve ve insana yönelik liderlik tarzlarının etkilerini inceleyen çalışmalar yeterli değildir. Daha önceki çalışmalar incelendiğinde, Ohio State Üniversitesinin liderlik çalıșmaları ile Blake ve Mouton'un Yönetim Tarzı Matriksi'nde liderlerin genel olarak insan ve göreve (üretim) yönelik bir liderlik tarzı sergilediği, bu iki tutumun farklı sonuçlar yarattığı gözlenmiştir. Bu kapsamda, göreve yönelik liderliğin verimliliği arttırdığı, çalışana yönelik liderliğin ise çalışanların iş tatminini arttırdığ 1 ifade edilmiştir. Ayrıca, göreve yönelik liderliğin ne tutumlar ne de verimlilik üzerinde açık bir şekilde etkili olmadığı, çalışana yönelik liderliğin ise çalışan tutumları üzerinde pozitif etkilerinin olduğuna yönelik görüşler vardır (Çekmecelioğlu, 2014: 28).

Konu ile ilgili daha önce yapılan araştırmalar da görev ve insana yönelik liderlik stilinin iş performansı, duygusal bağl1lık gibi farklı iş tutumları üzerindeki etkisi ayrıntılı olarak incelenmiş ve önemli sonuçlar elde edilmiştir. Bu bağlamda göreve yönelik liderliğin örgüte duygusal bağlllık üzerinde pozitif bir etkisinin olduğu, ancak çalışanların iş performansı üzerinde istatiksel olarak herhangi bir anlamlı etkisinin olmadığı ifade edilmiştir. Önceki araştırmalarda genel olarak liderin göreve ve örgütsel hedeflere ulaşılmasına önem veren davranışlarının daha çok performans ve verimlilik üzerinde etkili olduğuna yönelik bulgular vardır (Çekmecelioğlu, 2014: 28). İnsan/Görev odaklı liderlik tarzlarının performans üzerindeki etkisi üzerine yapılan benzer bir araştırmada insan odaklı liderlik eğilimi daha yüksek görülmekle birlikte görev yönelimli liderlik algılamasının da yakın düzeyde olması hem bağlamsal hem de görev performansını pozitif yönde etkilediği görülmüştür. Görev ve insan odaklı liderlik birbirinden bağımsız boyutlar olduğu için lider her ikisinin de farklı derecelendirmelerine sahip olabilmektedir. Liderin her iki tarzda yüksek eğilim göstermesinin en iyi liderlik tarzı olacağ 1 düşünülebilmektedir. Ancak her zaman geçerli en iyi liderlik tarzı olmadığı için 
Yalova Sosyal Bilimler Dergisi

durumsal değişkenlere uygun tarzın en iyi liderlik tarzı olduğu görülmektedir. Bulgulara göre ilişki yönelimli liderlik tarzının hem görev hem de bağlamsal performans1 daha yüksek oranda etkilediği görülmüştür. Dolayısıyla bu tarzı benimseyen liderlerin performansı artıracağı düşünülebilmektedir. Bundan sonra yapılacak olan çalışmalarda liderlik performans ilişkisi incelenirken örgüt kültürü, kişilik gibi ara değişkenlerin de modele dahil etmesiyle durumsal değişkenler de kullanılarak hangi durumlarda hangi liderlik tarzının daha etkili olacağına dair bulguların elde edilebileceği ifade edilmiştir (Özdevecioğlu ve Kanıgür, 2009: 79). Konu ile ilgili yapılan daha önceki çalışmalarla bu araştırma sonuçları arasında bazı farklılıklar gözlemlenmiştir. Bunların sebepleri arasında kültür, sosyal yapı, şehir, çalışılan kurum, örneklemin demografik özellikleri sıralanabilir.

Araştırmada elde edilen veriler ve yapılan analizler 1şı̆̆ında değişkenlerin birbirlerine olan etkileri incelenmiş ve aşağıdaki sonuçlar elde edilmiştir.

Görev odaklı liderlik tarzlarının. duygusal, devam ve normatif bağl1lık ile çalışan performansı üzerinde olumlu ve anlamlı bir etkiye sahip olduğu görülmüş̧ür. İnsan odaklı liderlik tarzlarının ise duygusal normatif ve çalışan performansı üzerinde olumlu yönde ve anlamlı bir etkiye sahip olduğu görülürken. devam bağl1lı̆ı üzerinde herhangi bir etkisinin bulunmadığı ve bir anlam taşımadığı görülmüştür. Liderlik tarzları karşılaştırıldı̆̆ında ise. görev odaklı liderlik tarzlarının. devam ve normatif bağlılık üzerindeki etkisinin. insan odaklı liderlik tarzından daha fazla olduğu görülmüsstür. Duygusal bağl1lık ve çalışan performansı üzerinde ise insan odaklı liderlik tarzının. görev odaklı liderlik tarzından daha fazla etkiye sahip olduğu görülmüştür.

Araştırmada örgütsel bağlılık boyutlarının çalışanların performansı üzerindeki etkileri de incelenmiştir.Örgütsel bağlılık boyutlarının. çalışan performansına etkilerine ilişkin model incelendiğinde. duygusal bağglılı̆̆ın çalışan performans1 üzerinde en yüksek düzeyde etkide bulunduğu görülmüştür. Devam bağlılığ çalışanların performansı üzerinde herhangi bir anlam ve etki taşımamaktadır. Normatif bağlılık ise düşük düzeyde bir etkiye sahip olmasına karşın bu etki düzeyi çalışan performansı üzerinde anlamlı bir etkiye sahip değildir. $\mathrm{Bu}$ bilgiler 1şı̆̆ında örgütsel bağlılı̆̆ın çalışan performansına etkisinde sadece duygusal bağl1lı̆̆ın bir anlam ifade ettiği sonucuna varılmaktadır.

Yerel yönetimler kapsamında bulunan bir kurumda yapılan bu araştırmada ulaşılan en önemli sonuçlardan biri çalışanların devam ve normatif bağlılıklarının. görev odaklı liderlik tarzlarından yüksek düzeyde etkilendiği sonucudur. Devam bağlılığına. insan odaklı liderlik tarzının anlamlı etkisi bulunmamaktadır. Çünkü bu bağl1lı boyutunda insanlar kendilerini kurumda zorunlu nedenlerden dolayı kalma duygusuna sahiptirler. Dolayısıyla. kişiler arası ilişkilerin düzeyi bu anlamda fazla etkin olmamaktadır. İnsan odaklı liderlik tarzının normatif bağlılık üzerinde olumlu etkisi bulunmaktadır ancak düzeyi görev odaklı liderlik tarzı kadar yüksek değildir. Devam bağlılığında çalışanlar. kurumlarına çok fazla çaba ve zaman harcadıklarını. yatırım yaptıklarını düşündüklerinden. kurumda kalmayı bir zorunluluk olarak görürler. Çalışanların örgüt ya da kurumdan ayrılması durumunda başka bir iş bulamayacağını düşüncesiyle de kurumda kalırlar. Normatif bağlılıkta ise çalışanlar örgütte kalmayı görev olarak görürler. Bu bağlılığa sahip çalışanlar. kendilerinin zor zamanlarında örgütün kendilerine iş verdiğini bunun için burada 
Yalova Sosyal Bilimler Dergisi

çalışmanın. onların örgüte karşı bir borcu olduğunu düşünürler. Görev odaklı liderlik tarzına sahip liderler. işi ve görevi ön planda tuttuklarından. devam bağl1lığ1 ve normatif bağl1lı̆̆a sahip çalışanların da bu eğilimde olması. görev odaklı liderlik tarzlarının devam ve normatif bağlılığa yüksek düzeyde etki etmesi sonucunu doğurmaktadır. Liderin otoritesi, disiplin anlayışı da bu bağl1lık düzeyinde etkili olabilir.

Araştırmada ulaşılan diğer önemli sonuçlardan biri de insan odaklı liderlik tarzları sergileyen liderlerin çalışanlarının duygusal bağlılığını ve performansını yüksek düzeyde etkilediğinin tespit edilmesidir. Görev odaklı liderlik tarzları da duygusal bağlılık üzerinde etkilidir. ancak düzeyi insan odaklı liderlik tarzı kadar yüksek değildir. Liderin astlarına cana yakın davranması onlarla iyi ilişkiler kurması ile moral ve motivasyon unsurlarının buna neden olduğu söylenebilir. Duygusal bağl1lığı yüksek olan çalışanlar kurum ya da örgütlerinin hedeflerini ve amaçlarını benimserler. Çalışanlar kendilerini örgütün bir parçası olarak kabul etmekte ve burada kendi isteği ile kalmaktadırlar. Bu çalışanların işe karşı sergiledikleri tutumlar genellikle olumlu olmaktadır. Çalışanlar kurumlarının değerlerini benimsemekte ve kendilerini kurumlarıyla özdeşleştirmektedirler. $\mathrm{Bu}$ durumda çalışanlar ideal bir mutluluk durumu yaşarlar. Duygusal bağl1lığın yüksek düzeyde olması çalışanların kurumlarıyla bütünleştiklerini göstermektedir. $\mathrm{Bu}$ düzeyin yüksek olması çalışanların bu kurumda kendi isteğiyle kaldıklarını gösterir.

Kurumlar ya da örgütlerin başarı düzeyi çalışanlarının sergilediği performansla doğrudan ilintiidir. Bir örgütün başarısının en önemli göstergesi ortaya koyduğu performansıdır. Çünkü çalışanların performansının artması örgütün performansını da arttırmaktadır. Araştırmada duygusal bağlılığın ve çalışanların performansının insan odaklı liderlik tarzlarından olumlu yönde ve yüksek düzeyde etkilendiği görülmüştür. Bu sonuç da konunun öneminin ne kadar büyük olduğunu göstermektedir.

Örgütsel bağlılığın çalışan performansına etkisi. bu çalışmanın bir diğer inceleme konusunu oluşturmuştur. Çalışan performansının en yüksek düzeyde etkilendiği bağl1lık boyutunun duygusal bağlilık olduğu görülmüştür. Devam ve normatif bağlılık boyutları çalışan performansı üzerinde herhangi bir anlam ifade etmemektedir. Buradan duygusal anlamda kendilerini örgütlerine ait hisseden çalışanların. performansının da yüksek olduğu sonucu ortaya çıkmaktadır. Diğer bir ifadeyle çalışanların kendileriyle kurumlarını özdeşleştirdikçe onunla bütünleştiklerini ve yüksek bağlılık duygusuna sahip çalışanların performansının da yükseldiği sonucuna ulaşılmaktadır.

Örgütlerde liderlerin çalışanlarına cana yakın davranmaları onların kendilerini rahat hissettirmelerini sağlamaları. görüş ve önerilere açık olmaları. adil olmaları. huzurlu bir ortam sağlamaları. kararlarını alırken astlarının tekliflerini de gözünde bulundurmaları duygu ve düşüncelerini zaman zaman astlarıyla paylaşmaları çalışanlarının birbirleriyle iyi ilişkiler içinde olmasını istemeleri ve çalışanların sorunlarını önemsemelerinin çalışanların örgütsel bağlılığın ve performansın arttırılmasında büyük etken olduğu ve örgütlerde bu değişkenlerin etkin. etkili ve verimli yönetilmesi örgütsel bağl1lığ1 ve performansı arttırmak için gerekli olduğu araştırma bulgularında ortaya çıkmıştır. 
İnsan görev odaklı liderlik tarzları üzerine yapılan bir araştırmada Çekmecelioğlu (2014) insana yönelik liderliğin gerek çalışan performansı gerekse örgüte bağlılı̆̆1 açısından daha önemli etkilerinin olduğu görülmüştür. Yapılan araştırma bir çok açıdan bu çalışma ile paralellik arz etmektedir. Bu nedenle bu araștırmanın sonuçları yöneticiler açısında oldukça anlamlı sonuçlar içermektedir. Yöneticiler özellikle insana yönelik liderlik tarzının ne denli pozitif sonuçlar yarattığının farkına varmalı ve bu yönde davranışlar sergilemelidir. Liderlik tarzları, lider davranışları hem örgüt hem de çalışanlar üzerinde oldukça önemli etkiler yarattığı için, bu konuda daha çok araştırma yapılmasına gerek vardır. $\mathrm{Bu}$ noktada, araştırmacıların gelecekte davranışsal liderlik teorisi üzerinde daha çok durmaları, görev ile insana yönelik liderlik tarzlarının iş tatmini, güçlendirme, motivasyon üzerindeki etkilerine dair incelemeler yapmaları önerilir (Çekmecelioğlu, 2014: 28).

Sonuç olarak liderlik tarzlarının görev odaklı ve insan odaklı olmasının çalışanların tutumları üzerindeki etkileri farklı olduğundan ve her durumda geçerli bir liderlik tarzı da bulunmadığından (Özdevecioğlu ve Kanıgür, 2009: 79) liderler durumsal değişkenleri de göz önünde bulundurarak kendisi çalışanları ve örgütüne uygun olan örgütsel bağl1lığın ve çalışan performansının artmasını ve etkinliğinin yükselmesini sağlayan davranışlar göstermelidir.

$\mathrm{Bu}$ çalışma bir ilçe belediyesinde yapılmıştır. Buna paralel olarak araştırma da ulaşılan çalışan sayısı sınırlı kalmıştır. Bu çalışmada ulaşılan sonuçların daha da geliştirilmesi amacıyla. benzer çalışmaların il ya da büyükşehir belediyelerinde de uygulanması ulaşılacak çalışan sayısını arttıracak ve bu konuda elde edilecek sonuçların daha geniş ve kapsamlı olmasına neden olabilecek bu alanda yapılan çalışmalara katkı sağlayabilecektir.

\section{Kaynaklar}

Ada N. Alver İ. ve Atlı F. (2008). "Örgütsel İletişimin Örgütsel Bağglllk Üzerine Etkisi: Manisa Organize Sanayi Bölgesinde Yer Alan Ve İmalat Sektörü Çalışanları Üzerinde Yapılan Bir Araştırma", Ege Akademik Bakış / Ege Akademic Review. 8 (2), 487-518.

Akgündüz A. (2001). Lider Yöneticinin El Kitabl, Genç Beyin Yayınlan, İstanbul.

Allen N. J, and Meyer J. P,(1990). "The Measurment and Antecedents Of Effective Continuance and Normative Commitment to Organization", Journal Of Occupational Psycology, Vol, 63, No,1,1-18.

Ataman G.(2001). İsletme Yönetimi, Türkmen Kitabevi, İstanbul.

Balay R, (2000). Yönetici ve Öğretmenlerde Örgütsel Bağllllk, Nobel, Ankara.

Bayraktaroğlu S.(2008). Insan Kaynakları Yönetimi, Sakarya Yayıncılık, Sakarya.

Barutçugil İ.(2002). Performans Yönetimi, Kariyer Yayınları, İstanbul.

Bayram L., "Yönetimde Yeni Bir Paradigma: Örgütsel Bağlllık", Sayıştay Dergisi, Say1:59, 125-139. 
Yalova Sosyal Bilimler Dergisi

Çekmecelioğlu, H.G (2014) "Göreve ve İnsana Yönelik Liderlik Tarzlarının Örgütsel Bağlllık, İs Performansı ve İsten Ayrlma Niyeti Üzerindeki Etkileri” KOSBED, 2014, 28: $21-34$.

Çırpan H.(1999). Örgütsel Öğrenme İklimi ve Örgütsel Bağlllk İlişkisi :Bir Alan Araştırması, İstanbul Üniversitesi, Sosyal Bilimler Enstitüsü İstanbul, (Yayımlanmamış Doktora Tezi).

Doğanay A.(2014). Liderlik Tarzlarının Çalışanların Bağlllık Seviyesi ve Performansına Etkisi : Başakşehir Belediyesinde Bir Uygulama, İstanbul Gelişim Üniversitesi, Sosyal Bilimler Enstitisü, Yüksek Lisans Tezi.

Doğan S. (2007). Vizyona Dayalı Liderlik, Kare Yayınları, 2,Bask1, İstanbul, 2007.

Doğan S. ve Kılıç S. (2007). "Örgütsel Bağlllğı̆n Sağlanmasında Personel Güçlendirmenin Yeri ve Önemi”, Erciyes Üniversitesi İktisadi ve İdari Bilimler Fakültesi Dergisi, Sayı: 29, Temmuz-Aralık, 37-61.

Duncan W, J.(1981), Organizational Behavior, Houghton Mifflin Company, Boston.

Eren E.(2010). Örgütsel Davranış ve Yönetim Psikolojisi, Beta, 12,Bask1, İstanbulk.

Erçetin Ş(2000). Lider Sarmalında Vizyon, Nobel Yayın Dağııım, 2, Baskı, Ankara.

Ekici K. M. (Ed) (2013), Yönetim Becerileri, Savaş Kitap ve Yayınevi, Ankara.

Griffin M.L, ve Hepburn J, R,(2005).“Side-Best and Reciprocity as Determinants of Organizational Commitment Among Correctional Officers", Journal of Criminal Justice, Vol,33, Iss, 6, November-December.

Güçlü H.(2006), Turizm Sektöründe Durumsal Faktörlerin Örgütsel Bağlllk Üzerindeki Etkisi, 1, Baskı, Anadolu Üniversitesi Yayınları, Eskişehir.

Güney S.(2013) Davranış Bilimleri, Nobel, İstanbul.

Gürüz D. ve Yaylacı G.Ö.(2007). Iletişimci Gözüyle İnsan Kaynakları Yönetimi, Mediacat Kitapları, İstanbul.

Hair J. F,, Black W., Tatham D. and Anderson R. E.(1998). Multivariate Data Analysis, $5, \mathrm{Ed}$.

Harvard Business School Press (2007). Pocket Mentor, Liderlik, Çev, Ahmet Kardam, İstanbul.

Hodgkinson C. (2008). Yönetim Felsefesi, Çev, Ed, İbrahim Anıl ve Binali Doğan, Beta, İstanbul.

İbicioğlu H. (2000). Örgütsel Bağlllkta Paradigmatik Uyumun Yeri, Dokuz Eylül Üniversitesi, İktisadi ve İdari Bilimler Fakültesi Dergisi, Cilt:15, Sayı:1,13-22.

İbicioğlu H., Özmen İ., TAŞ S.(2009). Liderlik Davranışı Ve Toplumsal Norm Illişkisi:Ampirik Bir Çalısma, Süleyman Demirel Üniversitesi İktisadi ve İdari Bilimler Fakültesi Dergisi Y.2009, C.14, S.2 s.1-23.

İnce M. ve Gül H. (2005). Yönetimde Yeni Bir Paradigma: Örgütsel Bağlllk, Çizgi Kitabevi, Konya. 
Yalova Sosyal Bilimler Dergisi

Kalaycı Ş. (2005) Uygulamalı Çok Değişkenli İstatistik Teknikleri, Asil Yayın Dağtım, Ankara.

Karahan A, (2008). Hastanelerde Liderlik Ve Örgütsel Bağlllik Arasındaki İlişkinin Incelenmesi, Sosyal Bilimler Dergisi / Cilt: X, Say1 1, Haziran 2008,145-162.

Karaman A. (2005). Vizyon Yönetimi, IQ Kültür Sanat Yayıncılık, 1,Bask1, İstanbul.

Koçel T. (2005). İsletme Yöneticiliği, Arıkan, 10,Bası, İstanbul.

Özalp İ. (1994). Yönetim ve Organizasyon, Cilt, I, Birlik Ofset, Yayıncıllk, Eskişehir.

Özdevecioğlu M. (2003). "Algllanan Örgütsel Destek İle Örgütsel Bağllllk Arasindaki Ilişskilerin Belirlenmesine Yönelik Bir Araştırma”, Dokuz Eylül Üniversitesi, İktisadi ve İdari Bilimler Fakültesi Dergisi, Cilt:18 Sayı:2, 113 -130.

Özdevecioğlu M. ve Kanıür S., (2009) Çalışanların Iliş̧ki ve Görev Yönelimli Liderlik Algilamalarının Performanslarn Üzerindeki Etkileri, KMU İ̈BF Dergisi Yll:11 Sayl:16 Haziran/2009, 53-82.

Özgen H. (2001). İnsan Kaynakları Yönetimi, Nobel Kitabevi, Adana.

Özler D.E.(Ed,) (2012). Örgütsel Davranışta Güncel Konular, Ekin Yayınevi, İstanbul.

Robbins S.P, ve Judge T. A. (2012), Örgütsel Davranıs, Çev, İnci Erdem, 14,Basım, Nobel, İstanbul.

Sabuncuoğlu Z. ve Tüz M. (2003), Örgütsel Psikoloji, Furkan Ofset, 4,Bask1, Bursa.

Saldamlı A. (2009). İsletmelerde Örgütsel Bağlllk ve İsgören Performansı, Detay Yayıncilik, Ankara.

Saltürk M. (2008). Yönetim Başarısı ve Kişilik, Toplumsal Dönüşüm Yayınları, İstanbul.

Şimşek M.Ş. vd.(1998). Davranış Bilimlerine Giriş ve Örgütlerde Davranış, Nobel, Konya.

Tahiroğlu F.(Ed,)(2004). insankaynaklari,com'dan İşte Başarı, Hayat Yayınları, Erntst and Young, İstanbul.

Tengilimlioğlu D.(2008), İ̧sletme Yönetimi, Seçkin, Ankara.

Tutar H. ve Erdönmez C.(2008) İşletme Becerileri Grup Çalışması, 5, Baskı, Detay Yayıncilik, Ankara.

Uysal O.(2007). Liderliğin Anatomisi, Akçağ Yayınları, Ankara.

Ünal M.(2012.), 21,YY’da Değişim, Yönetim ve Liderlik, Beta, İstanbul.

Vural Z, B.A. ve Coşkun G.(2007). Örgüt Kültürü, Nobel Yayın Dağıtım, Ankara. 